ГЕНЗЕ Валерия Михайловна

аспирант кафедры лингвистики и межкультурной коммуникации ДВФУ (г. Владивосток).

Электронная почта: genze_vm@dvfu.ru

\title{
Контркультурный дискурс в контексте рок-музыки (на материале британской рок-группы Muse)
}

\section{УДК 811.111-26}

контркультура,

контркультурныц

дискурc,

рок-дискурс,

рок-музыка,

речевое воздействие
Для иитирования:

Гензе В. М. Контркультурный дискурс в контексте рок-музыки (на материале британской рок-группы Muse) // Известия Восточного института. 2021. № 3 . C. $122-131$. DOI https://doi. org/10.24866/2542-1611/2021 3/122-131
DOI https://doi.org/10.24866/2542-1611/2021-3/122-131

В данной работе рассмотрено явление контркультурного дискурса на примере текстов песен британской рок-группы Muse. Рок-музыка с момента зарождения является протестным и выполняет одну из основных функций - апеллятивную. Выполнение данной функции достигается при помощи речевого воздействия, в первую очередь лексическими и грамматическими средствами. Альбом Drones поднимает остросоциальную тему лишения свободы и манипулирования сознанием. Средства речевого воздействия, в свою очередь, как нельзя лучше позволяют донести этот посыл, обращаясь к эмоциям и социальным установкам слушателей.

Задачей данной статьи является рассмотрение рок-дискурса как контркультурного явления и речевых средств передачи протестных идей.

На протяжении существования музыкального жанра рок воспринимался как протестный и контркультурный. Это обусловлено как эпохой зарождения жанра, так и жанрами-предшественниками, из которых постепенно сформировалось рокдвижение.

Рок-музыка возникла во второй половине 1960-х годов время расцвета движения хиппи в США. Данное движение возникло как противопоставление общепринятой культуре, музыке и политике. Известный лозунг хиппи «Make love, not war!» отлично отражает философию и идеологию движения ненасилие, свободу и мир. Хиппи продвигали уход от общества, поглощённого войной, чрезмерным потребительством и насилием. Они использовали творчество для распространения своей философии - против милитаризма и конформизма.

Как музыкальный жанр рок развился из рок-н-ролла, бывшего на пике популярности в 40-50-х годах. Рок-н-ролл в свою очередь вобрал в себя черты таких жанров, как блюз, джаз, кантри и госпел. Все эти жанры изначально были музыкой чёрного населения США, берущие начало из обрядовой, ритуальной музыки и «рабочей песни». Такая музыка отражала социальные проблемы афроамериканцев, была выражением свободы и силы духа этого народа.

В Британии рок-музыка стала популярна также в 60-х годах, когда набравший в США популярность рок-н-ролл вышел за границы страны и приступил к завоеванию Европы. Однако популярная в США музыка оказалась в Британии под запретом. И как любой запрещенный продукт вызвала живой интерес у британской молодежи. Стали появляться подпольные группы, по-своему интерпретирующие новый жанр. 
Такие экспериментальные группы дали начало трем вариациям рокн-ролла - танцевальному, «тяжелому» и фолк направлениям.

Все эти факторы повлияли не только на музыку и исполнителей, но и на принимающую сторону - слушателей. Появление рок-музыки привело к формированию музыкальных субкультур. Люди, относящие себя к одной субкультуре, связаны не только схожим внешним видом - стилем в одежде, прическах, атрибутике, но и поведением, схожими взглядами и философией. Соответственно, те идеи, что несёт та или иная группа принимаются, разделяются и распространяются среди участников субкультуры. Рок-музыканты уже не просто ещё один исполнитель, но рупор, передатчик как своих мыслей и настроений своим фанатам, так и мыслей и настроений своих фанатов дальше в общество и власть держащим. Рок-музыканты воспринимаются как представители контркультурного движения, выражающие недовольство властью, неравенством и несправедливостью [8, с. 476].

Контркультура встает в оппозицию культуре - системе ценностей и норм, поддерживающих социализацию общества, а также совокупность артефактов, знаний, верований, выражающих адаптацию и репродуцирование жизненного уклада человечества [2, с. 43].

Впервые термин «контркультура» был использован американским социологом Дж. М. Йингером в 1960-м году в статье «Контркультура и субкультура». Дальнейшее распространение термину дал другой американский социолог Т. Роззак. Отечественный ученый П.С. Гуревич вслед за рядом учёных (Д. Белл, Т. Роззак, Э. Тирьякян, Дж. Уэбб) рассматривает контркультуру как инструмент преображения и движения культуры. Контркультурные тенденции, возникая как оппозиция сложившимся общепринятым установкам, постепенно принимаются культурой, таким образом меняя ценности и их восприятие в обществе. «Контркультура постоянно проявляет себя в виде механизма культурных новаций» $[1$, с. 366].

Рок-музыка как раз и послужила одним из таких механизмов. Начавшись с движения хиппи, рок-движение поспособствовало переосмыслению ряда ценностей - «... этики труда, смысла жизни, отношений между полами, традиций рациональности» $[1$, c. 366].

Таким образом, и субкультуры, и исполнители рока приобретают новый статус контркультуры, то есть противопоставляют себя общепринятым нормам, взглядам и моралям. Такой статус позволяет поднимать непопулярные темы, такие как войны, дискриминация, расизм, несправедливость, превышение полномочий и многое другое. Каждое из направлений рок-музыки - панк, хеви-метал, хард-рок и другие - порождали субкультуру, приобретающую черты контркультуры, которая отвергала ценности массовой культуры и проповедовала свои свободы, несогласие с устоявшимися принципами.

Рок-дискурс выполняет апеллятивную функцию, эмоционально воздействуя на слушателя и привлекая его внимание к поднимаемым проблемам посредством речевого воздействия.

Под речевым воздействием вслед за И.А. Стерниным мы понимаем «воздействие человека на другого человека или группу лиц при помощи речи и сопровождающих речь невербальных средств для достижения поставленной говорящим цели» $[6$, с. 51].

Целью нашего исследования является рассмотрение лингвистических средств воздействия в контркультурном рок-дискурсе.

В лингвистике в рамках коммуникативно-прагматической парадигмы выделяют три основные разновидности речевого воздействия: обращение к эмоциям (обращение к достаточно примитивным чув- 
ствам (страху, гневу, ненависти, основному инстинкту»), обращение к социальным установкам (социальное самочувствие человека - разделение на "своих» и «чужих», стремление «быть как все», стремление повысить свое место в иерархии), обращение к представлениям о мире (образ действительности, структура ценностей и набор рецептов деятельности) [5, с. 54].

В данной статье рассмотрим виды воздействия посредством анализа таких инструментов, как выбор лексики и синтаксиса и обращение к когнитивным и логическим операциям.

Материалом исследования послужили тексты песен из альбома Drones британской рок-группы Muse. Группа существует с 1994 года, обладает множеством значимых музыкальных наград и популярностью по всему миру. Начавшись как подростковая рок-группа, исполняющая каверы известных песен, Muse постепенно искали свой неповторимый стиль, звучание и тематику.

Контркультурный дискурс начинает впервые проявляться в их третьем альбоме Absolution (2003). Звучание группы сменилось с мажорного на минорное, тексты композиций приобрели политический окрас. Такое изменение было вызвано нестабильной ситуацией в мире, началом военного конфликта США и Британии с Ираком, повсеместным недовольством и недоверием к власти. Все больше появлялось песен, выражающих озабоченность автора текстов Мэтью Белами будущим человечества, страхи общества перед возможными военными конфликтами и повсеместным контролем корпораций над умами обычных людей.

Все эти темы в итоге воплотились в альбоме Drones (2015), в котором в полной мере раскрылся потенциал Muse как контркультурной группы.

Альбом Drones, выигравший премию Грэмми за Лучший рокальбом 2015 года, поднимает проблемы засилья современных технологий, уничтожения всего человеческого в людях и безразличия к окружающему миру [9].

Альбом состоит из 12 композиций, названия которых ярко и кратко иллюстрируют основную идею альбома - преобладание искусственного над человеческим и насильная «роботизация» человечества. Со слов автора песен и исполнителя Мэтью Белами Drones (с англ. - «Дроны») выступают метафорой превосходства технологий над человечностью и «дегуманизации современных способов ведения войны» [7]: Dead Inside (Mертв внутри), [Drill Sergeant] ([Сержантинструктор]), Psycho (Психопат), Mercy (Милость), Reapers (Жнеи, ), The Handler (Манипулятор), [JFК], Defector (Дезертир), Revolt (Восстание), Aftermath (Последствия), The Globalist (Глобалист), Drones (Дронь).

Альбом показывает развитие и противостояние двух персонажей - протагониста и антагониста. Протагонист - обычный человек, попавший в систему и подвергающийся обработке - уничтожению всего человеческого в нем. Антагонист же воплощает представителей правительства, которым нужны бездушные исполнительные роботы. Последовательность композиций также играет роль. В альбоме чередуются песни от лица протагониста и антагониста, передавая их диалог и подчеркивая их противостояние друг другу. Такой посыл и 
порядок композиций обеспечивает восприятие альбома как сильного инструмента контркультурного воздействия.

Лексический анализ текстов позволяет выделить две доминантные тематические группы: религиозная лексика и военная лексика. Религиозная лексика (ablaze, alive, holiness, prayers, soul), вызывает ассоциации со святостью и благочестием. В то время как техническая и военная лексика (authorization, base, drones, program, remote control, virus) иллюстрирует мир жестокий и бездушный.

Религиозная лексика широко используется в композициях Dead Inside (Мертв внутри), Mercy (Милость), Revolt (Восстание), посвящённых внутренней и внешней борьбе протагониста с манипуляцией и попытками контроля его разума и действий.

Одним из ключевых понятий всех трёх композиций является дуща (soul), которая ассоциируется со способностью к состраданию. Это и предположение об отсутствии души у антагониста:

Do you have no soul It's like it died long ago ('Dead Inside')

И опасение, что душа протагониста может быть съедена «темными силами»:

Save me from the ghosts and shadows

Before they eat my soul.

And all the men in cloaks

Trying to devour my soul ('Mercy')

Здесь же следует обратить внимание на подбор глагола. Они не просто съедят душу (they eat my soul), но поглотят еe (devour my soul).

И уже в одной из последних композиций альбома Revolt (Восстание) автор призывает слушателя вспомнить о наличии столь ценной материи как «душа» и не позволить угнетателям её забрать и уничтожить:

Don't try to hide it, don't tell me it's not there...

You've got strength,

You've got soul ('Revolt')

Наибольшее количество религиозной лексики присутствует в первой композиции Dead inside (Mертв внутри), где протагонист осознает, что он уподобляется антагонисту:

Revere a million prayers

And draw me into the holiness

But there's nothing there

On the outside you're ablaze and alive

But you're dead inside! ('Dead Inside')

Эффект, создаваемый религиозной лексикой, усиливается противительными конструкциями, разрушающими положительный образ.

Так же следует отметить последнюю композицию альбома Drones (Дроны) и структурно, и музыкально построенную наподобие церковных песнопений: 
Killed by drones

My mother, my father, my sister and my brother, my son and my daughter, Killed by drones.

Our lives between your finger and your thumb

Can you feel anything?

Are you dead inside?

Now you can kill from the safety of your home with drones

Amen ('Drones')

Военно-техническая лексика наиболее ярко передаёт дух войны и армии в композициях [Drill Sergeant] ([Сержант-инструктор]) и Psycho (Пcuхоnam). Первая композиция представляет собой диалог между сержантом и новобранцем:

- If you do not do what you are told to do, when you're told to do it, you will be punished, do you understand?!

- Aye, sir!

- If you leave my base without proper authorization,

I will hunt you down and throw your ass in jail! Do you understand?!

- Aye, sir! - I can't hear you?!

- Aye, sir! - Scream it!!!

- Aye, sir!!!- Your ass belongs to me now!!!

Aye, sir!!! ([Drill Sergeant])

В речи сержанта явно прослеживается стратегия запугивания. Это не только подбор лексики с негативной коннотацией (hunt you down, throw in jail, belong), демонстрирующей безоговорочную власть сержанта, но и грамматических структур: you will be punished, I will hunt you down - создают ощущение неизбежности и неотвратимости этих угроз.

В композиции Psycho (Психоnam) мы слышим продолжение этого диалога и можем наблюдать превращение новобранца-человека в нечто дикое и неразумное - в дрона, машину:

- Are you a human drone?!- Aye, sir!

- Are you a killing machine?!- Aye, sir!

- I'm in control motherfucker, do you understand?!

- Aye, sir!

- Are you a psycho killer?! Say 'I'm a psycho killer'?!

- I'm a psycho killer! - Scream it!!!

- I'm a psycho killer!!! - Show me your war-face!!!

- Arrrrrrr!

- You are a pussy! I said 'show me your war-face'!!!

- Arrrrrrrrr!!!! ('Psycho')

В речи сержанта появляется всё больше обсценной лексики (motherfucker, pussy). Тон высказываний повышается, о чём свидетельствует наличие всё большего количества восклицательных знаков. Теперь сержант не запугивает новобранца, но внушает тому, кем он является - a human drone (человек-дрон), a killing machine (машина для убийства), a psycho killer (убийца-nсихопат). Именно эти образы ярко передают основную идею альбома - дегуманизация и превосходство технологий над человечностью. 
В противовес речи сержанта слова солдата ограничиваются лишь единственной фразой согласия - Aye, sir! - как бы подчеркивающей его безвольность и полное подчинение. И последняя фраза-возглас (Arrrrrrrr!!!) демонстрирует отречение от человечности в сторону чего-то животного.

В этой же композиции тема бездушной техники продолжается и в куплете. Видно, что повествование идет от лица антагониста, для которого главный герой не более чем программа, робот, которым он может управлять. Интересно также заметить, что антагонист сравнивает себя с вирусом (virus), подразумевая скрытый контроль:

\author{
Your mind is just a program. \\ And I'm a virus \\ I'm changing a station ('Psycho')
}

Композиция Reapers (Жнецы) так же развивает тему войны и техники. Во-первых, отметим фразу - By your Drones! (Killed by) Drones! (Killed by) (Твоими дронами! (Убит) Дронами!) - рефреном идущую через всю композицию. Данная фраза завершает оба куплета, описывающих состояние антагониста и мира в целом. В первом куплете сравнение дома с полем боя (killing field) подчеркивает, что в этом мире не осталось безопасного места, война теперь везде. Метафора обезличенной войны развивается ярким образом отсутствия коголибо у руля (there's no one behind the wheel):

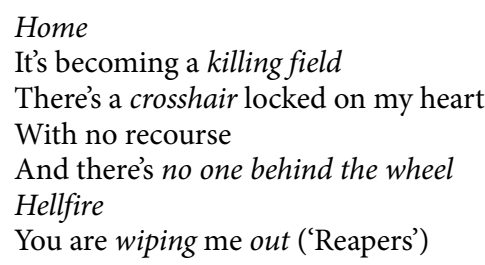

Во втором куплете впервые за весь альбом присутствует слово война (war). И эта война только набирает обороты (moved up a gear). Существительное pawn (пешка) добавляет метафору «война шахматы», где все мы - расходный материал (expendable). Наречия incidentally (случайно), electronically (электронно) подчеркивают идею бездушности и бездумности действий антагониста:

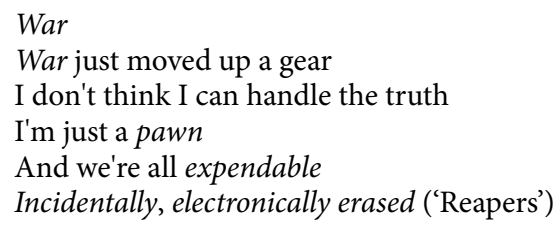

В альбоме ярко поднимается антивоенная тема, раскрываемая определённой лексикой. Однако в противовес этому весь альбом скрыто пронизан темой свободы. Тема и ценность свободы доносится скорее через оппозицию лексике манипуляции и контроля, раскрывающей тему войны и роботизации. Данная тема не выражается соответствующей лексикой, она нагнетается через обращение к эмоциям и 
социальным установкам. В большинстве случаев создаётся ощущение безысходности и безвольности.

Для создания образа антагониста, отнявшего свободу и волю, используется ряд синонимов с отрицательной коннотацией манипулятора (tyranny, puppeteer, oppressor, handler). Усиливается данный образ окружающей лексикой. В композиции Mercy (Милость) прилагательное silent (тихий) перекликается с образом вируса (virus) из композиции Psycho, подчеркивая скрытность такого контроля:

\section{Absent gods and silent tyranny \\ We're going under \\ Hypnotised by another puppeteer ('Mercy')}

В этой же композиции причастие hypnotized (загипнотизированный) идёт в паре со словом рирреteеr (кукловод), развивая идею управления скрытого и недобровольного.

Композиция The Handler (Манипулятор) уже своим названием задаёт слушателю тему отсутствия свободы. С первых же строк нам демонстрируется изменение восприятия героем антагониста. Если в прошлом он выступал в роли угнетателя (oppressor), то сейчас роль изменилась на манипулятора (handler). Соответственно и уровень контроля увеличился. В то время как страдательная конструкция $I$ have been programmed to obey исключает протагониста как субъекта действия, то во фразе I will execute your demands отражена некоторая добровольность действий протагониста и полное принятие власти манипулятора:

You were my oppressor

And I, I have been programmed to obey

Now, you are my handler

And I, I will execute your demands ('The Handler')

Намерение антагониста контролировать и подавлять отражено в композиции Psycho (Психопат), исполненной от первого лица. Наличие формы будущего времени и разговорной формы конструкции I am going to добавляет коннотацию уверенности в безоговорочном подчинении:

I'll turn you into a super drone

And you will kill on my command,

And I won't be responsible

I'm gonna make you, I'm gonna break you,

I'm gonna make you a fucking psycho! ('Psycho')

Глаголы make, break так же демонстрируют полный контроль антагониста и безволие протагониста.

Однако в композиции Defector (Дезертир) вся лексика, связанная с подавлением воли, сопровождается отрицательной частицей not, подтверждающей освобождение протагониста из-под гнета тирана:

Free, yeah, I'm free

From your inciting.

You can't brainwash me

You've got a problem. 
Free, yeah I'm free

From society.

You can't control me

I'm a defector ('Defector')

Кроме вышеупомянутых лексических и грамматических средств следует обратить внимание на обращение к когнитивным операциям, ярким представителем которых являются прецедентные тексты ${ }^{1}$. Примером использования прецедентного текста является композиция $[J F K]^{2}$. Как название композиции, так и ее текст являются актуализацией личности Джона Ф. Кеннеди (29.05.1971 - 22.11.1963), 35-го президента США. В композиции [JFK] используется отрывок записи речи Дж. Кеннеди в 1961 году с обращением к прессе, призывающей СМИ разоблачать злые намерения и открыто говорить правду. Данная композиция полностью состоит только из части записи этой речи:

$$
\begin{aligned}
& \text { For we are opposed around the world } \\
& \text { By a monolithic and ruthless conspiracy } \\
& \text { That relies primarily } \\
& \text { On covert means for expanding ... ([JFK]) }
\end{aligned}
$$

В альбоме неспроста использована речь именно этого политического деятеля. Следует помнить, что для англоязычного слушателя, и в первую очередь американского, Дж. Ф. Кеннеди является личностью культовой и значимой. Он не только был харизматичным лидером, боровшимся с расовой дискриминацией, но и человеком, прошедшим войну и отмеченным наградами за храбрость.

Еще одним ярким примером использования прецедентного текста является композиция Defector (Дезертир), символизирующая освобождение от контроля манипулятора.

Эта композиция является ключевой в истории протагониста. Герой освобождается от гнета манипулятора. Именно здесь впервые используется прилагательное free (свободныц̆), которое до конца альбома будет не раз присутствовать в композициях наравне с существительным freedom (свобода). Герой заявляет об этом радостном событии восклицанием Free, yeah, I'm free (Свободен, да, я свободен), которое повторяется на протяжении всей композиции. Меняется и тон песни с тяжёлого и давящего на более лёгкий и мажорный. Вся песня - гимн свободе:

$$
\begin{aligned}
& \text { Free, yeah, I'm free } \\
& \text { From your inciting. } \\
& \text { You can't brainwash me } \\
& \text { You've got a problem. } \\
& \text { Free, yeah I'm free } \\
& \text { From society. } \\
& \text { You can't control me } \\
& \text { I'm a defector. ('Defector') }
\end{aligned}
$$

Песня завершается еще одним отрывком из той же речи Дж. Ф. Кеннеди 1961 года, провозглашающим свободу и независимость:

We look for strength and assistance

Confident that with your help

\author{
1 Прецедент- \\ ные тексты - (1) \\ значимые для той \\ или иной личности \\ в познавательном \\ и эмоциональном \\ отношениях, (2) \\ имеющие сверхлич- \\ ностный характер, \\ т. е. хорошо извест- \\ ные и широкому \\ окружению данной \\ личности, включая \\ её предшествен- \\ ников и современ- \\ ников, и, наконец, \\ такие (3), обра- \\ щение к которым \\ возобновляется \\ неоднократно \\ в дискурсе данной \\ языковой личности \\ [3, c. 216]. \\ 2 John Fitzgerald
Kennedy
}


Man will be what he was born to be:

free and independent ('Defector')

Данный отрывок как бы ставит точку в противостоянии героя и антагониста, сообщая слушателю о близкой победе и счастливом завершении истории протагониста - человека свободного и независимого.

Таким образом, рок, появившись в середине 20-го века «из сознания невыносимой отчуждённости всех традиционных форм общественности, науки, религии, искусства от жизни, от повседневного существования обычного простого человека» [4, с. 34], выполняет апеллятивную функцию, донося протестные идеи и установки до слушателей. Рок-музыка является ярким примером контркультурного дискурса, воздействующего на слушателя прежде всего посредством лексических и грамматических средств.

\section{Литература}

1. Гуревич П.С. Культурология: учебник М.: КНОРУС, 2011. 448 с.

2. Ершова Ю. Я. Культура, субкультуpa, контркультура: дефиниция и демаркация понятий // Вестник СПбГУКИ. 2016. № 4 (29). C. $42-45$.

3. Караулов Ю. Н. Русский язык и языковая личность М.: Издательство ЛКИ, 2010. 267 c.

4. Кнабе Г.С. Рок-музыка и рок-среда как формы контркультуры // Избранные труды. Теория и история культуры. М.: Летний сад, 2006. С. 20-50.

5. Пирогова Ю.К. Рекламный текст: семиотика и лингвистика / Ю.К. Пирогова,

П.Б. Паршин. М.: Международный институт рекламы, Издательский дом Гребенникова, 2000. 270 с.

6. Стернин И.А. Введение в речевое воздействие Воронеж: Воронежский государственный университет, 2001. 252 с.

7. AllMusic: сайт. URL: https://www. allmusic.com/album/drones-mw0002836779 (дата обращения: 26.08.2021).

8. Bennett A. "Heritage rock": Rock music, representation and heritage discourse // Poetics. 2009. № 37. p. 474-489.

9. MuseWiki: сайт. URL: https://www. musewiki.org/Drones_(album) (дата обращения: 26.08.2021). 
Valeriya M. GENZE,

Postgraduate student, Department of Linguistics and Intercultural Communication, FEFU (Vladivostok, Russia).

E-mail: genze_vm@dvfu.ru

\section{Counter-Cultural Discourse in the Context of Rock-Music (Based on the Lyrics of the British Rock-Band Muse)}

UDC 811.111-26

DOI https://doi.org/10.24866/2542-1611/2021-3/122-131

An analysis of the phenomenon of counter-cultural discourse counter-culture, represented in the lyrics of the British rock-band Muse is counter-cultural reported in this paper. From its very beginning rock-music discourse, implements one of the most important functions - an appellative, rock-discourse, or persuasive, function. The function is performed via linguistic rock-music, persuasion, primarily by lexical and grammatical means. The album Drones raises the acute social topics of deprivation of linguistic persuasion freedom and manipulation of mind. Therefore, the means of linguistic persuasion are able to carry this message in the best possible way, addressing the emotions and social settings of audience.

For citation: Genze V. M. Counter-cultural discourse in the context of rock-music (based on the lyrics of the British rock-band Muse) // Oriental Institute Journal. 2021. № 3. P. 122-131. DOI https://doi.org/10.24866/2542$1611 / 2021-3 / 122-131$

\section{References}

1. Gurevich P.S. Kul'turologiya: uchebnik M.: KNORUS, 2011. 448 s.

2. Ershova YU. YA. Kul'tura, subkul'tura, kontrkul'tura: definitsiya i demarkatsiya ponyatij // Vestnik SPbGUKI. 2016. № 4 (29). S. $42-45$.

3. Karaulov YU. N. Russkij yazyk i yazykovaya lichnost' M.: Izdatel'stvo LKI, 2010. 267 s.

4. Knabe G.S. Rok-muzyka i rok-sreda kak formy kontrkul'tury // Izbrannye trudy. Teoriya i istoriya kul'tury. M.: Letnij sad, 2006. S. 20-50.

5. Pirogova YU.K. Reklamnyj tekst: semiotika i lingvistika / YU.K. Pirogova,
P.B. Parshin. M.: Mezhdunarodnyj institut reklamy, Izdatel'skij dom Grebennikova, 2000. $270 \mathrm{~s}$.

6. Sternin I.A. Vvedenie $\mathrm{v}$ rechevoe vozdejstvie Voronezh: Voronezhskij gosudarstvennyj universitet, 2001. $252 \mathrm{~s}$.

7. AllMusic: sajt. URL: https://www. allmusic.com/album/drones-mw0002836779 (data obrashheniya: 26.08.2021).

8. Bennett A. "Heritage rock": Rock music, representation and heritage discourse // Poetics. 2009. № 37. p. 474-489.

9. MuseWiki: sajt. URL: https://www. musewiki.org/Drones_(album) (data obrashheniya: 26.08.2021). 